\title{
Research on Strengthening Ideological Education of College Students' innovation and Entrepreneurship
}

\author{
Yao Yao ${ }^{1, a}$, Mengyuan Cheng ${ }^{2, b}$ \\ 1,2 Jiangxi Vocational Technical College of Industry \&Trade, jiangxi, nanchang, 330038 \\ a3107000933@qq.com \\ b739960103@qq.com
}

\begin{abstract}
Adhering to the purpose of personnel training and using new methods to lead students to start their own businesses are the ultimate goal of improving the moral quality of Ideological and political courses in Colleges and universities. Encouraging college students to start their own businesses can help economic development, produce social value, and improve China's international status and development momentum.
\end{abstract}

Keywords: college students, Innovation and entrepreneurship, Ideological Education

\section{大学生创新创业加强思想教育的研究}

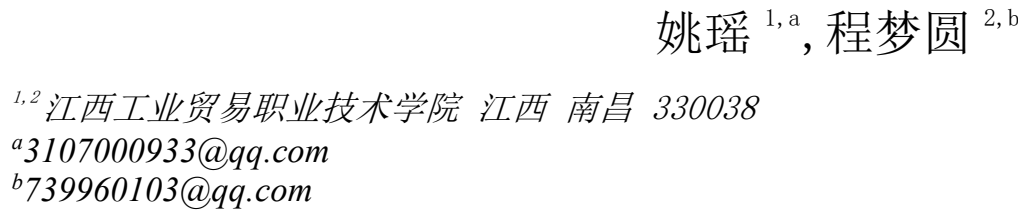

摘要:

坚持人才培养的目的，使用新的方法来带领学生自己创业，这些是现在高校思想政治课提高道德素质的最终 目的。鼓励大学生自主创业, 可以帮助经济发展, 生产社会价值, 可以提高中国国际地位以及发展动力。

关键词: 大学生; 创新创业; 思想教育

\section{1. 引言}

以大学生思想教育为载体, 了解和掌握创新创业 思想产生的条件、过程及其形式和特点, 研究影响 学生创新创业思想变化的主要因素, 从而掌握创新创 业思想活动的特点和规律, 积极推进创新创业教育工 作的实施, 增强思想教育的针对性和实效性。

促进高等院校大学生创业全新方式的建成, 有 助于中国生产力发展, 生产动力更加充足, 促进产 业升级, 也可以帮助提高高等院校教育水平, 为学 生毕业以后发展提供全新的思路。按照现在的社会 背景, 学校应该发现每个学生的特点以及长处, 并 且培养和发展这些优点, 提高学生的自信心, 开拓 学生的就业思路, 提高学生的实际操作水平。这样 可以满足中国未来经济和社会发展的需要, 也可以
帮助大学生全面发展, 社会和经济的进步需要大量 人才, 当前的学生不仅要掌握课本知识, 也要有高 水平的社会实践能力, 这样才能适应以后的工作生 活。

\section{2. 创新创业与思想教育}

个性化人才培养的过程中，创新创业教育占有 重要的位置, 另外, 要想让个性化培育工作得到有 效的开展, 就要重视对大学生开展的创新创业教育 教学,

采取措施, 鼓励学生把课本知识应用到实际工 作中，让学生推动新的生产力发展，加快经济发展 速度，提高我国国际地位。 


\section{1. 大学生创新与创业}

创造是创新思维方式和高水平的实际操作的结 合。他的表现是在原来工作基础上, 改变原有的固 有思维, 提出全新的动力。创业是指工作者在合适 的时间拥有高水平的管理方式, 其中有创业技术和 创业目标两个方面。创业和创造可以表现出创新的 优点, 创业的精神内核就是创新, 而创业是创新的 社会表现。当前应该。鼓励所有人创业, 拥有创新 思维, 而现在的国家经济发展现状就要求学生增强 大学生的创新思维方式教育, 应该是用信息技术归 纳整合资源, 把专业课汇总起来, 让学生拥有灵活 多变的思考方式以及开拓新方法的勇气。

\section{2. 创新创业与思想教育}

因为原有观念的根深蒂固, 大部分人对创新创 业教育持反对的态度, 针对创新创业开展的实践是 缺少的, 要想改变这样的现状, 语需要重视对大学 生创新创业教育工作的开展。教师要合理利用教育 教学时间过程中的相关内容, 比如思想观念和道德 法规等, 让学生得到全方位的发展, 帮助学生养成 良好的身体素质和心理素质, 形成正确的价值观和 世界观, 同时培养学生的综合素养, 让其更好地开 展创新创业实践工作。随着社会的飞速发展, 越来 越多的领域需要创新型人才, 因此对于大学生来说, 就更加需要具备创新理念和能力。

\section{3. 创新创业与思想教育的内容}

高等院校逐渐扩大招生的作用下，使得毕业后 的大学生就业越来越困难。依据当今社会发展新趋 势, 增强学生创新创业素养显得更为重要。在好高 校具备的教书育人的基础上, 结合社会对创新型人 才的实际需要, 对大学生进行有效的教育教学实践, 在这个过程中增强学生的创新创业能力和水平, 提 升大学生的就业率。

\section{1. 创业意识教育}

现如今大学生就业是一个十分艰巨的难题, 从 本质上看, 是因为大学生普遍缺乏一定的职业生涯 发展规划, 同时并没有实际了解和深度分析目前的 就业状况。因为传统教育思想根深蒂固, 对于大学 生创新创业并不重视。针对这种情况进行创新创业 的针对性教学, 会让学生更好地了解创新创业的实 际情况, 意识到创新创业在实际社会中的巨大作用, 帮助学生增强创新能力, 同时帮助学生提升自身的 综合素养和职业规划能力, 以便在以后的创新创业 实践过程中更好地应对相关问题。

\section{2. 创业观念教育}

现如今, 创业观念错误是大学生中普遍存在的 问题。一些创业者觉得理念是创业的重心, 创业过 程的作用相对弱化; 但是也有创业者觉得创业具有很 大风险, 在一定情况下可以凭借机会和运气来创业, 这样的想法显然是不正确的, 需要在后续创新创业 教育中提醒并纠正。在创业理念的培养过程中, 可 以借助思想教育来让学生形成正确的纪念, 同时还 可以依据有关的评价考核来让学生深刻把握创新创 业理念的紧要性。让学生能够独立自主对创业难题 进行探讨和解决。并在开展实践课程时充分将学生 对创新创业内容的主动积极性激发出来。

\section{3. 创业精神教育}

如今很多人不相信创新创业, 因此创业没有在 毕业生的就业选项之中。改变传统的落后理念, 让 学生逐渐形成创新创业素养, 让学生把握当前创新 创业形式有利于社会经济整体发展。从如今的就业 状况来看, 大学生既要在职场中找到自己的位置, 又要依据自己的能力来转换角色, 力争工作岗位的 创造者。高校要不断提升学生的创新创业技能和创 新理念, 让更多的学生加入到大众创业万众创新的 社会趋势中并成功创业。

\section{4. 创业意志教育}

由于大学生创业人员数量的逐渐增长, 少数学 生在创业期间会出现慌张、忧郁、躁急的心理以及 萎靡不振、妄自菲薄的恶劣结果, 经过对学生进行 创新创业意识的专业课程教学, 提供学生的抗打击 能力水平, 从而降低创业挫折产生的消极影响。可 以和创业成功学生的经验相融合, 以事例解析为基 础从而帮助学生深入学习创业理论知识, 熟练创新 创业技能, 正确了解到创业期间会产生的风险以及 会出现的挑战, 为学生进入社会提供动力, 降低学 生在创业过程中产生的负面影响, 从而来强化学生 的创新创业意识。

\section{4. 创新创业教育与思想教育的有效开展}

当前很多高校已经开展了创新创业教育, 然而 因为教育课程较少, 再加上其他的一些高校客观因 素, 使得创新创业教育实际开展情况不统一。高校 可以依据通常的思想教育课程来帮助学生形成创新 创业意识, 树立科学正确的创业理念。同时还要为 学生打造一个优良的创新创业气氛, 让学生投入到 创新创业气氛中, 让一些有创新创业经历和经验的 教师来为学生讲解创新创业实践知识。 


\section{1. 创新人才培养目标}

和如今社会发展所需要的人才培养要求相结合, 深入研究以创新创业为发展方向的人才发展制度, 强化人才的综合素养水平和实际操作能力, 发展学 生努力拼搏、积极向上的乐观精神。探究全方面多 渠道的人才发展制度, 可以适度在人才培养期间投 入一些社会资源与资金，提供学生的实践能力水平, 从而培养出符合新时代发展需要的复合型人才, 推 动学生全方位多层次进步。激励专业老师与辅导员 发展符合大学生能力的实验活动, 把普通的课程教 学和创新创业训练相结合, 经过实际联系、创业竞 赛、创新结果转别等多种教学阶段, 慢慢探究概括 适应于学生个人特征的教学模式。

\section{2. 完善课程体系}

面对如今的社会创新创业条件以及学生的创新 创业能力, 对如今的教学制度进行完善升级。专业 课程教学需要冲破科目束缚, 进而发展出符合相关 专业的通课以及跨领域的穿插课程, 强化课程教学 制度的内在关联。在进行专业课教学期间, 和实际 情况相结合, 了解本专业正在研究发展的问题, 指 引学生进行相关课题的探究, 从而使专业课程教学 和创新创业向结合。现阶段各高校需要建立起完善、 规范的课程机制, 不仅要考虑到社会需求的发展变 化, 还需要将理论知识课程与实践课程有效结合在 一起, 充分发挥出互联网技术的价值, 为学生创设 出一个高质量的学习平台, 以此来为学生提供更加 多样化的课程内容。

\section{3. 改进考评方式}

考核方法在高校教育中占据着至关重要的位置, 它不仅可以促进高校教育的发展, 还可以使学生在 学习过程中及时了解自身的不足。教师在开展教学 活动时可以通过考核方式来分析学生的学校情况和 心理活动, 不仅需要考核学生的理论知识能力, 还 需要考核学生的实践技巧, 充分发挥出考核方式的 价值。在考核办法方面, 应该对学生的主体地位进 行强化, 进一步培养学生的创造性思维, 让学生可 以更加积极主动的投入到创新和创业实践考核的过 程中去, 使 “高分低能” 现象不再出现, 不仅要保 证学生的理论学习, 同时还要尽可能的把精力放到 平时的创新实践活动中去, 充分发挥考评方法作为 杜杆的作用, 充分激发学生的热情和积极性, 推动 创新创业实践实现成果转化，从而提高成功的概率。

\section{4. 强化教育实践}

高校在开展创新创业教育时需要不断完善相关 的教学设备, 为学生提供更加充足的实践场地, 比 如: 建设多样化的实验室、增加多媒体设备, 增加实 训场地对学生的开放时长, 使每位同学都有时间、
有机会到实训场地来参加实践活动。高校要认识到 教育设施的重要性, 不断完善自身的教育设施, 以 此来为学生提供更好的学习环境和成长环境。

学校在开展课堂教学时需要考虑到每位学生的 不同学习需求以及创新创业教育的教学目的, 安排 专业能力较高的教师来指导学生的实践活动, 让每 位学生都有机会参与到实践活动中, 使学生可以通 过创新创业实践活动来了解改课程的理论思想, 使 学生可以将所学的理论知识运用到实际实践中。除 此之外, 学校还需要为创新创业教学提供充足的资 金支持和人力支持，为学生介绍一些成功的实际案 例, 提高学生对该课程的学习兴趣。

\section{5. 加强教师队伍建设}

现阶段创新创业教学在师资力量上还存在一些 不足, 所以学校需要为创新创业教学提供充足的资 金支持和人力支持，通过一些培训方式来不断增强 师资力量, 不仅要注重对教师开展理论知识教学, 还需要注重提高教师的实践能力。因为没有充分的 知识储备以及丰富的实践经验, 在创新创业的指导 方面, 没有相成较为理想化的效果, 针对性以及可 操作性较低。所以各高校应该加强教师队伍建设, 让教师积极主动地投入到创新创业的学习当中, 亲 身感受创新创业实践活动的各个流程, 在亲身感受 之后, 把得到的技巧与理念对学生进行传授。与此 同时，还应该对创新创业方面的职业发展路线进行 优化与完善，对专业技术职业的评聘标准以及具体 要求做到进一步的明确, 给创新创业方面的师资队 伍实现可持续性发展提供坚实的保障。

把大学生思想教育平台作为依托, 举办有关创 新创业方面的教育教学活动, 充份发挥大学生思想 教育教学在育人方面的作用, 以个性化的方式设计 思想教育新的途径。在创新人才培养目标的基础上, 对课程体系进行完善与优化，同时强化教育实践的 相关内容, 对考评方式进行改进, 形成较强的师资 队伍力量等, 开展与创新创业相关的主题教育活动, 坚持学生的主体地位, 进一步端正创业观念, 充分 调动大学生在创新创业方面的积极性, 激励学生积 极参加实践活动, 为学生打造良好的创业环境, 同 时为他们提供展示自身个性的大舞台, 以科学化的 手段, 有序开展好培养创新型人才的相关工作。

\section{5. 结论:}

综上所述, 各高校应该积极地培养学生形成较 强的创业创新思想, 通过科学化、合理化的手段与 方式, 激发学生的热情与积极性, 并且通过一系列 的实践与活动, 潜移默化的培养学生对于创新创业 的兴趣, 助推学生成长成才, 提高学生在各方面的 能力。 


\section{REFERENCES}

[1] Shen Hongming. On the current situation, problems and Countermeasures of the cultivation of entrepreneurial psychological quality in Colleges and universities in China [J]. Journal of Inner Mongolia Normal University: Education Science Edition, 2008 (9): 8890

[2] Gao Xiaojie, Cao Shengli. Innovation and Entrepreneurship Education -- training pioneers of new era undertakings -- Summary of the seminar on innovation and entrepreneurship education of Chinese society of Higher Education [J]. China higher education research, 2007 (7): 91-93

[3] Jing Yongchun, Yang Ting, Tang Chunyong. The deviation and correction of supply and demand of high skilled talent team construction policy: a case study of Sichuan Province [J]. China human resource development, 2020, 37 (1): 127-142

[4] Kan University, LV Lianju. Empirical analysis on the impact of industry university research collaborative innovation on independent innovation capability: Based on the data of Jiangxi Province [J]. Science and technology management research, 2017, 0 (7): 19-25

[5] Jing Yongchun, Yang Ting, Tang Chunyong. The deviation and correction of supply and demand of high skilled talent team construction policy: a case study of Sichuan Province $[\mathrm{J}]$. China human resource development, 2020, 37 (1): 127-142

[6] Yi Na, Shi Jianping, Wei Lisi, Wang Yarong. The core influencing factors of the concentration of innovative and entrepreneurial talents identified by Inner Mongolia University Students [J]. Operation and management, 2018, 0 (11): 75-78

[7] Yi Na, Shi Jianping, Wei Lisi, Wang Yarong. The core influencing factors of the concentration of innovative and entrepreneurial talents identified by Inner Mongolia University Students [J]. Business and management, 2018, 0 (11): 75-78

[8] Ding junmiao. Innovation and entrepreneurship education leading the reform and development of Higher Education - three stages of innovation and entrepreneurship education and the new historical mission of colleges and universities [J]. Innovation and entrepreneurship education, 2016,7 (1): 1-6

[9] Zhao Peiyang, Du Jun. visualization analysis of university students' innovation and Entrepreneurship Education Research Based on CiteSpace [J]. Innovation and entrepreneurship education, 2019,0 (6): 11-18

[10] Construction of practical teaching system in Colleges and universities from the perspective of innovation and Entrepreneurship Education -- Taking educational technology as an example [J]. Jiang Dan, Zou Dexin. Guangxi Education. 2016 (35)

[11] Construction of practical teaching system in Colleges and universities from the perspective of innovation and Entrepreneurship Education -- Taking educational technology as an example [J]. Jiang Dan, Zou Dexin. Guangxi Education. 2016 (35)

[12] Zhou Liang, Pan Hong, Wang Xin. Xi Jinping's basic principles, main ways and general train of thought in China's new era of socialism with Chinese characteristics in the ideological and political classroom [J]. Journal of Kunming University of Science and Technology (SOCIAL SCIENCES), 2019 (6): 37 - 43 .

[13] Wang Jingyun. The structure, operation and evaluation of the discourse field of external communication: a case study of the high level dialogue between the Communist Party of China and world political parties [J]. Journal of Suzhou University: Philosophy and Social Sciences, 2020, 41 (4): 79-85

[14] Gu Hai Liang. Theoretical guidance and development concept of Ideological and political education in New Era: learning Xi Jinping's ideological and theoretical education guide in China's new era of socialism with Chinese characteristics, 2018 (1): 4 - 10., [J].

[15] Zhu Jiao, Li Xue, Liu Tong, et al. Based on the "great ideological and political" perspective, Xi Jinping's new era of China's socialist ideology "three progressive" teaching methods research $[\mathrm{J}]$. contemporary education practice and teaching research (Electronic Journal), 2018, (12): 688699

[16] Cai Yaping. Discussion on talent training mode based on Supply Chain Information Sharing -- taking human resource management as an example [J]. Modern business industry, 2010, 22 (22): 5-6

[17] Xu Xiaolei. Analysis on the application of new media in the cultivation of student party members from the perspective of supply chain management $[\mathrm{J}]$. Research on modern basic education, 2015, 19 (3): 70-74 